\title{
Cardiac septal umbrella for closure of a tracheoesophageal fistula
}

We describe the use of a cardiac septal occluder (Amplatzer septal occluder [ASO]; AGA Corporation, Plymouth, Minnesota, USA), which is commonly adopted to close cardiac septal defects [1], but was used in the present case to treat an 83-year-old patient with a benign tracheoesophageal fistula (TEF). The TEF, which was caused by the accidental ingestion of dental amalgam, was previously treated unsuccessfully by the placement of a plastic covered stent, metal clips, and fibrin glue injection $[2,3,4]$.

The occluder device consists of a nitinol wire mesh shaped into two umbrellas linked by a metal connecting portion inserted through a catheter. Discs are covered by a polyester fabric favoring the growth of tissue over the mesh ( $\bullet$ Fig. 1). The fistula was cannulated from the esophagus by a double lumen papillotome for endoscopic retrograde cholangiopancreatography. A guide wire inserted into the papillotome was pushed and captured in the hypopharynx. After the endoscope was withdrawn, the wire was left in situ with both ends coming out of the mouth. A Mullins catheter (Medtronic, Minneapolis, Minnesota, USA) was introduced over the guide wire from the esophagus to the trachea; after removal of the guide wire, the ASO was inserted into the Mullins catheter. The distal umbrella was released on the tracheal side, the proximal one on the esophageal side ( $\bullet$ Figs. 2 and 3; Video 1).

Two months later the fistula orifice enlarged, the ASO migrated into the bronchial tree ( Fig. 4), and it was removed from the middle lobe bronchus.

During the subsequent 2 months, two overlapping partially covered metal stents were placed. The patient remained asymptomatic for the next 10 months.

\section{Video 1}

The video shows endoscopic images of: (1) the tracheoesophageal fistula and its cannulation by the papillotome; (2) guide wire insertion and Mullins catheter pushing in the trachea space; (3) Deployment and release of the Amplatzer septal occluder in the trachea and esophagus.
This report shows that the ASO failed to repair the TEF, despite its correct placement, and put the patient at risk of airway obstruction. ASO migration and fistula enlargement could be caused by esophagealtracheal wall fragility. These data are dif-

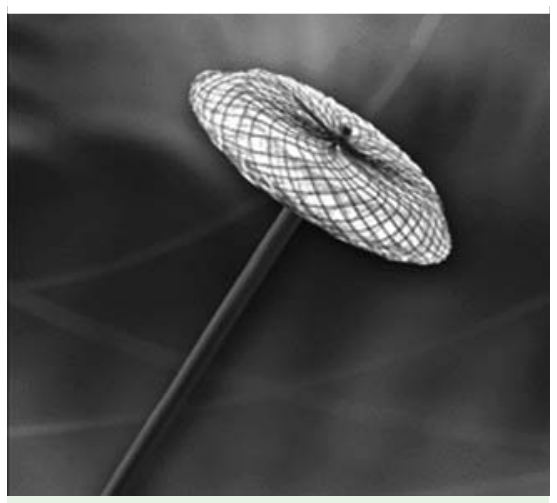

Fig. 1 The Amplatzer septal occluder.

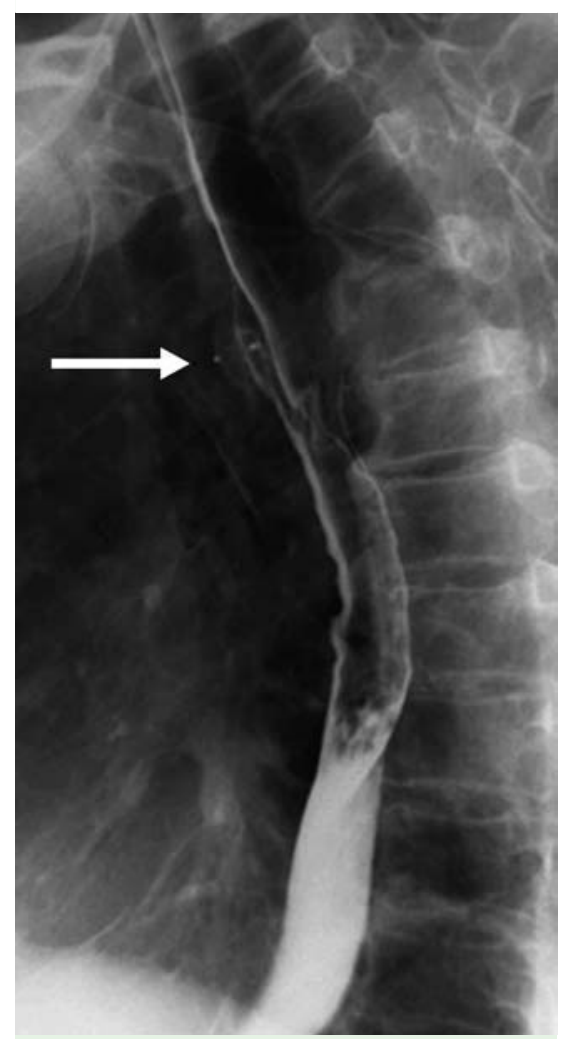

Fig. 2 Fluoroscopic image showing the cardiac septal occluder placed between the esophageal and tracheal walls (arrow). ferent from a recent study that reported the successful closure of TEF [5].

\section{Competing interests: None}

\section{Endoscopy_UCTN_Code_TTT_1AO_2AI}

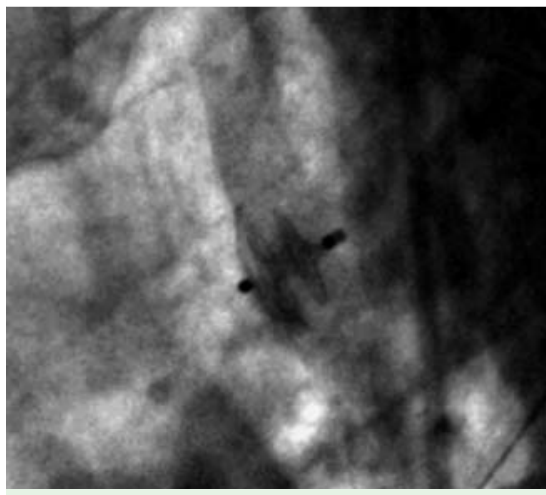

Fig. 3 Detail of $\bigcirc$ Fig. 2 showing the two Amplatzer septal occluder umbrellas after deployment.

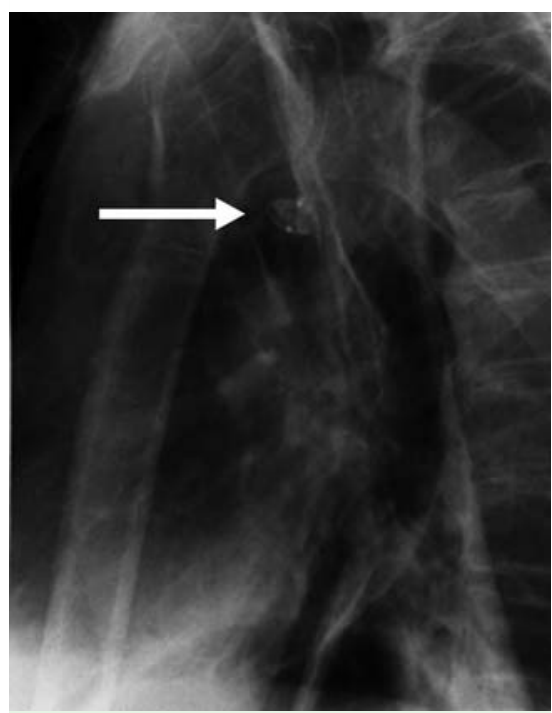

Fig. 4 Migration of Amplatzer septal occluder outside the esophageal wall (arrow). 
F. Coppola ${ }^{1}$, G. Boccuzzi ${ }^{2}$, G. Rossi ${ }^{3}$, S. Gaia ${ }^{4}$, M. Cosimato ${ }^{1}$, S. Recchia ${ }^{1}$

1 Department of Gastroenterology, San Giovanni Bosco Hospital, Torino, Italy

2 Department of Cardiology, San Giovanni Bosco Hospital, Torino, Italy

3 Department of Pneumology, San Giovanni Bosco Hospital, Torino, Italy

4 Department of Gastrohepatology, San Giovanni Battista Hospital, Torino, Italy

\section{References}

1 Knepp MD, Rocchini AP, Lloyd TR, Ajyagari $R M$. Long-term follow-up of secundum atrial septal defect closure with the amplatzer septal occluder. Congenit Heart Dis 2010; 5: $32-37$

2 Chauhan SS, Long JD. Management of tracheoesophageal fistulas in adults. Curr Treat Options Gastroenterol 2004; 7: 31 - 40

3 Eleftheriadis E, Kotzampassi K. Temporary stenting of acquired benign tracheoesophageal fistulas in critically ill ventilated patients. Surg Endosc 2005; 19 (6): 811 - 815. Epub 2005 May 3

4 Hoelzer DJ, Luft JD. Successful long-term endoscopic closure of a recurrent tracheoesophageal fistula with fibrin glue in a child. Int J Pediatr Otorhinolaryngol 1999 May 25; 48 (3): $259-263$

5 Repici A, Presbitero P, Carlino A et al. First human case of esophagus-tracheal fistula closure by using a cardiac septal occluder. Gastrointest Endosc 2010 Apr; 71 (4): 867 869. Epub 2010 Feb 24
Bibliography

DOI $10.1055 / \mathrm{s}-0030-1255822$

Endoscopy 2010; 42: E318 -E319

(c) Georg Thieme Verlag KG Stuttgart · New York . ISSN 0013-726X

\section{Corresponding author}

\section{F. Coppola, MD}

San Giovanni Bosco Hospital

Piazza del donatore di sangue 3

20154, Torino

Italy

Fax: +39-011-2402079

fvcoppola@libero.it 